\title{
Farm employment and wage patterns in the mid-1980s
}

\author{
Philip L. Martin $\quad \sqsupset \quad$ Greg Miller
}

\begin{abstract}
Wages paid to hired workers make up the single largest production expense for California crop and livestock farmers, and they rose $11 \%$ between 1984 and 1988. Crop and livestock employment is becoming concentrated on fewer, larger farms, and labor contractor employment is becoming fragmented among smaller contractors.
\end{abstract}

California agriculture depends on the hired workers who do 75 to $80 \%$ of the state's farm labor. The wages paid to these workers made up $27 \%$ of the $\$ 11$ billion in production expenses reported by farmers in the 1987 Census of Agriculture. The cost and availability of farm labor became more critical in the 1980s, when immigration reforms made it illegal for a farmer to knowingly hire illegal alien workers.

Between 1984 and 1988, the wages paid for seasonal agricultural services (crop-farm work and farm-oriented agricultural services) rose $17 \%$. At the same time, growers shifted to hiring more through farm labor contractors (FLCs). The FLC share of total wages for seasonal agricultural services rose from 10 to $12 \%$ while the share of those wages paid by general crop farms fell from 13 to $10 \%$ and the share paid by vegetable and melon farms fell from 16 to $14 \%$. The shift toward labor contractors was more pronounced in some counties. In Monterey County, for example, vegetable crop employment fell by $17 \%$ between 1984 and 1988, while FLC employment rose by $151 \%$.

\section{Employment concentration}

In 1988, almost 35,000 agricultural employers paid $\$ 5$ billion to the equivalent of 420,000 full-time workers (table 1). California's UnemploymentInsurance(UI) system requires that all employers paying wages of $\$ 100$ or more report the names, social security numbers, wages paid, and weeks worked for all employees each quarter. The employers pay a tax of 2 to $5 \%$ on the first $\$ 7,500$ of wages paid to each employee. The tax covers the cost of Unemployment Insurance benefits for jobless workers. California's Employment Development Department (EDD) began publishing quarterly UI data by commodity and county in the 1987 EDD
Report 882. Our report is based on the same data set that served as the basis for Report 882.

Virtually all California farm employers must obtain UI reporting numbers, report their workers and wages, and pay theUI tax, so the UI system should constitute a functional "census" of farm employment. Undoubtedly, some growers do not comply with the law, but there are no state or federal estimates of noncompliance; enforcement officers generally agree that agriculture is not a "special problem" industry as, for example, is construction. When compared to Census of Agriculture data, the UI data report fewer employers and more wages paid. Because there is no incentive to understate wages on the Census of Agriculture, this comparison suggests that the smaller employers who report their hirings to the Census but not to UI authorities do not account for a significant share of total farm employment.

The Standard Industrial Classification (SIC) system is a set of identification codes developed by the Federal Office of Management and Budget to classify economic activity. SIC divides agriculture into three segments: crop production (SIC 01), live-

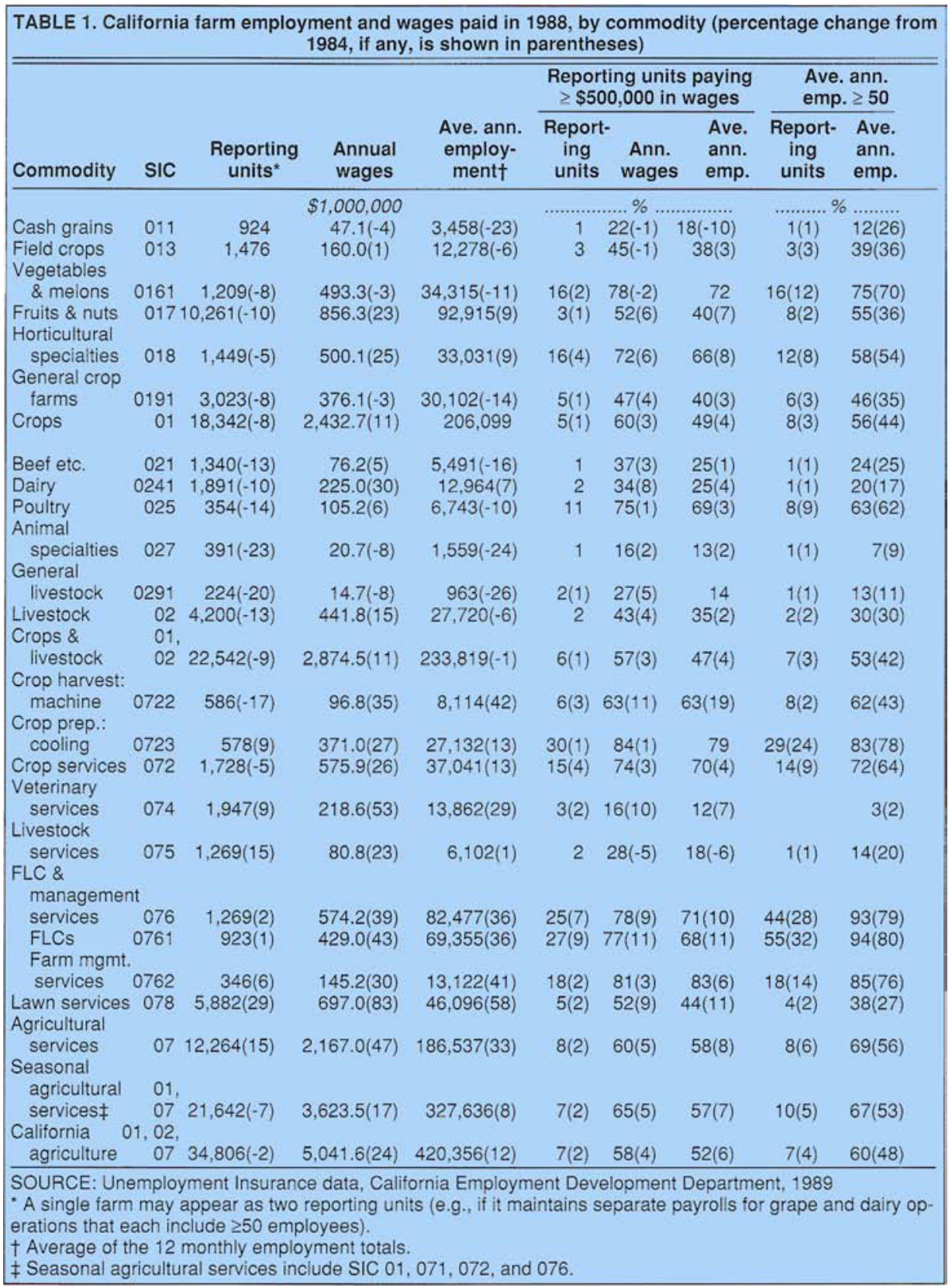



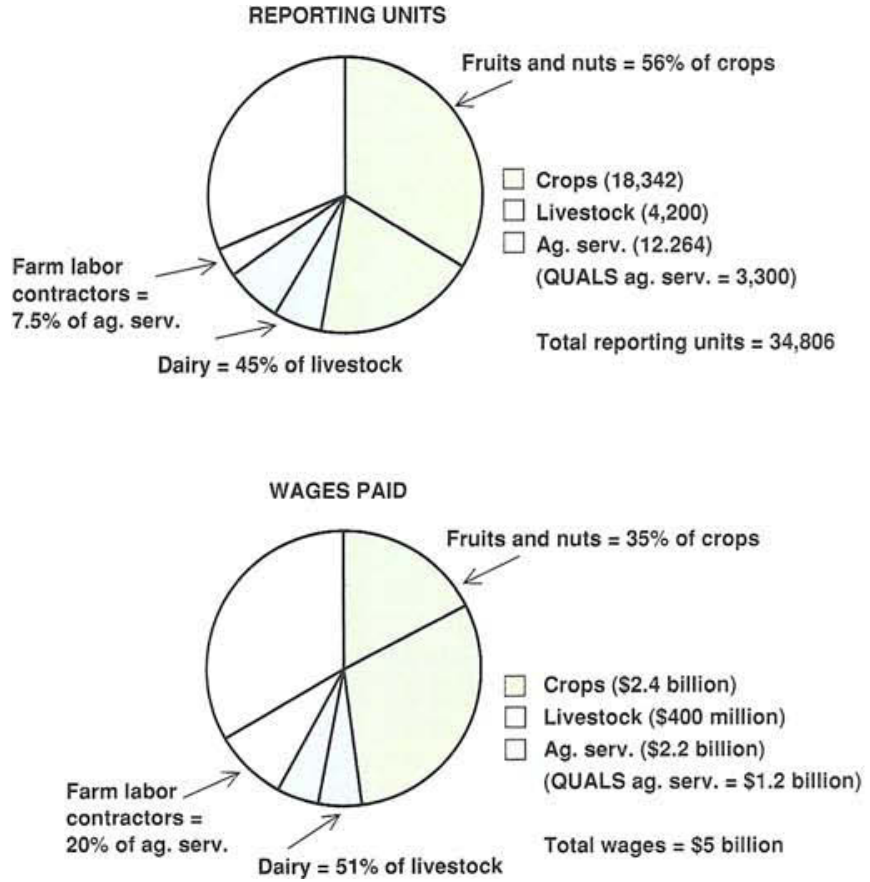

Source: Unemployment insurance flles, Employment Development Department, 1988

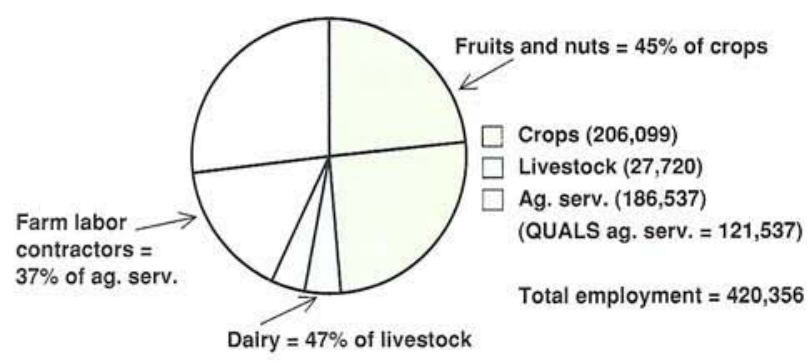

SEPTEMBER EMPLOYMENT

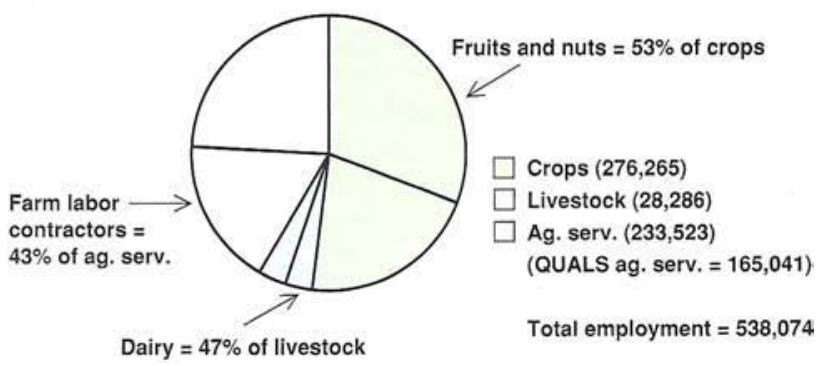

Fig. 1. Agricultural wage and employment data for California, 1988.

In an agricultural county, a single activity orSIC code usually accounts for half or more of the wages paid in crops, livestock, or farm-oriented agricultural services. Employment in this dominant activity is usually concentrated on a handful of farms, so that 50 or fewer large farm employers account for 50 to $80 \%$ of a county's farm employment. Recognizing this phenomenon is important when interpreting farm labor patterns: both the number and the size of each employer contacted are important when determining the farm labor trends within an area.

This type of concentration is evident in major agricultural counties (table 2). In Monterey County, for example, more than two-thirds of the crop wages are paid by vegetableand melon farms, and the 50 largest vegetable farms pay almost $90 \%$ of the county's vegetable wages. Similarly, the largest 34 custom harvesters and the largest 30 labor contractors in Monterey County account for $95 \%$ of the wages paid by employers engaged in these activities.

Similar patterns can be observed in other farm counties. Imperial County agriculture is dominated by general crop farms (farms that do notget $50 \%$ or more of their revenues from a single crop category, such as vegetables and melons). In 1988, the 22 largest general crop farm employers accounted for almost two-thirds of the wages paid by general crop farms, and the 16 largest labor contractors accounted for $80 \%$ of FLC wages. In Fresno County, more than half of the crop employers are grape producers, and the 19 largest grape producers paid one-fourth of all grape wages. Fresno County includes 
$20 \%$ of California's farm labor contractors, and the 46 largest FLCs paid more than $75 \%$ of Fresno County's FLC wages.

\section{Changes between 1984 and 1988}

During the mid-1980s, the number of crop and livestock employers fell while the number of agricultural service firms rose. Since farm production was on the increase, these data indicate that California farmers hired more workers through custom harvesters and FLCs. There were decreases in the number of California vegetable and melon employers, fruit and nut employers (except berries), and horticultural and generalcropfarmemployers, but thesedecreases were accompanied by increased total wages, indicating that more of the employment was concentrated on large farms. Livestock employment followed similar trends: the number of reporting units was down and wages were up.

Agricultural service employment trends were different. Instead of fewer and larger employers, there were more medium-sized reporting units that paid $\$ 50,000$ to $\$ 500,000$ in wages. This increased fragmentation of agricultural service employmentinto smaller units around the state stands in sharp contrast to the increased concentration of crop and livestock employment.

Between 1984 and 1988, the number of small employers decreased and the number of large employers increased in the crop category, indicating that crop employment was becoming more concentrated on a few large farms. Large employers accounted for an increased proportion of the direct-hire employment in citrus, tree fruits, and other fruits such as avocados, so that the 24 largest California citrus employers paid $52 \%$ of the direct-hire citrus wages in 1988 (additional citrus workers were hired through FLCs). If large size is measured as an average annual employment of 50 persons or more, the increased concentration of employment was especially pronounced in all fruit and nut crops except berries.

TABLE 2. Farm employment and wages paid in 1988 for three California counties, by commodity (percentage change from 1984, if any, is shown in parentheses)

\begin{tabular}{|c|c|c|c|c|c|c|c|c|c|}
\hline \multirow[b]{2}{*}{ Commodity } & \multirow[b]{2}{*}{ SIC } & \multirow[b]{2}{*}{$\begin{array}{c}\text { Reporting } \\
\text { units }^{\star}\end{array}$} & \multirow[b]{2}{*}{$\begin{array}{l}\text { Annual } \\
\text { wages }\end{array}$} & \multirow{2}{*}{$\begin{array}{l}\text { Ave. ann. } \\
\text { employ- } \\
\text { ment† }\end{array}$} & \multicolumn{3}{|c|}{$\begin{array}{l}\text { Reporting units paying } \\
\geq \$ 500,000 \text { in wages }\end{array}$} & \multicolumn{2}{|c|}{$\begin{array}{l}\text { Ave. ann. } \\
\text { emp. } \geq 50\end{array}$} \\
\hline & & & & & $\begin{array}{l}\text { Report- } \\
\text { ing } \\
\text { units }\end{array}$ & $\begin{array}{l}\text { Ann. } \\
\text { wages }\end{array}$ & $\begin{array}{l}\text { Ave. } \\
\text { ann. } \\
\text { emp. }\end{array}$ & $\begin{array}{l}\text { Report- } \\
\text { ing } \\
\text { units }\end{array}$ & $\begin{array}{l}\text { Ave. } \\
\text { ann. } \\
\text { emp. }\end{array}$ \\
\hline \multicolumn{2}{|c|}{ Monterey County } & \multicolumn{3}{|c|}{$\$ 1,000,000$} & \multicolumn{3}{|c|}{$\ldots \ldots \ldots \ldots$} & \multicolumn{2}{|c|}{$\ldots \ldots \ldots . . . . . . . .}$. \\
\hline \multicolumn{10}{|c|}{ Vegetables } \\
\hline \& melons & 0161 & $173(-8)$ & $164.4(-9)$ & $8,758(-17)$ & $31(5)$ & $89(-1)$ & 87 & $21(2)$ & $81(-1)$ \\
\hline Berries & 0171 & $90(10)$ & $18.6(18)$ & $1,748(12)$ & $13(1)$ & $70(-6)$ & 62 & $10(-3)$ & $57(-15)$ \\
\hline Crops & 01 & $448(-3)$ & $239.4(-5)$ & $14,707(-9)$ & $20(3)$ & $82(-2)$ & 78 & 13 & $71(-4)$ \\
\hline Livestock & 02 & $66(-23)$ & $3.4(-35)$ & $235(-35)$ & $(-1)$ & $(-26)$ & $(-19)$ & $(-1)$ & $(-19)$ \\
\hline \multicolumn{10}{|c|}{ Farm labor con- } \\
\hline cractors & 0761 & $45(32)$ & $51.6(146)$ & $6,831(151)$ & $67(28)$ & $94(14)$ & $91(15)$ & $73(26)$ & $97(10)$ \\
\hline \multicolumn{10}{|l|}{ Seasonal } \\
\hline $\begin{array}{l}\text { agricultural } \\
\text { services } \neq\end{array}$ & $\begin{array}{l}01, \\
07\end{array}$ & $602(2)$ & $423.7(18)$ & $29,136(23)$ & $29(6)$ & $87(1)$ & $85(6)$ & $23(3)$ & $82(3)$ \\
\hline $\begin{array}{l}\text { County } \\
\text { agriculture }\end{array}$ & $\begin{array}{r}01,02 \\
07\end{array}$ & $774(2)$ & $433.7(17)$ & $29,851(22)$ & $31(7)$ & $85(2)$ & $83(6)$ & $18(2)$ & $80(3)$ \\
\hline \multicolumn{10}{|l|}{ Imperial County } \\
\hline \multicolumn{10}{|l|}{ Vegetables } \\
\hline \multicolumn{10}{|l|}{$\begin{array}{l}\text { \& melons } \\
\text { General crop }\end{array}$} \\
\hline farms & 0191 & $139(-16)$ & $38.9(33)$ & $2,451(18)$ & $16(7)$ & $62(21)$ & $67(22)$ & $8(4)$ & $51(24)$ \\
\hline Crops & 01 & $311(-16)$ & 77.2 & $5,471(-6)$ & $13(5)$ & $61(7)$ & $64(2)$ & $7(2)$ & 50 \\
\hline Livestock & 02 & $55(-24)$ & $10.9(-8)$ & $532(-30)$ & $11(3)$ & $41(4)$ & $56(9)$ & $4(-3)$ & $21(-16)$ \\
\hline \multicolumn{10}{|l|}{ Seasonal } \\
\hline \multirow{2}{*}{$\begin{array}{l}\text { agricultural } \\
\text { servicesł }\end{array}$} & 01, & & & & & & & & \\
\hline & $\begin{array}{r}07 \\
0102\end{array}$ & $482(-12)$ & $137.9(17)$ & $12,548(13)$ & $15(6)$ & $70(8)$ & $68(8)$ & $11(3)$ & $71(7)$ \\
\hline $\begin{array}{l}\text { County } \\
\text { agriculture }\end{array}$ & 07 & $550(-12)$ & $149.4(15)$ & $13,126(10)$ & $19(7)$ & $68(8)$ & $67(8)$ & $10(3)$ & $69(7)$ \\
\hline \multicolumn{10}{|l|}{ Fresno County } \\
\hline Fruits \& nuts & 017 & $2,564(-14)$ & $146.5(18)$ & 20,533 & 1 & $46(8)$ & $29(5)$ & 2(1) & $35(8)$ \\
\hline Grapes & 0172 & $1,884(-12)$ & $61.7(9)$ & $10,991(-5)$ & 1 & $25(3)$ & $14(3)$ & 1 & $16(1)$ \\
\hline Crops & 01 & $3,378(-12)$ & $273.4(13)$ & $30,571(-3)$ & $3(1)$ & $51(7)$ & $35(6)$ & $3(1)$ & $38(7)$ \\
\hline Livestock & 02 & $221(-19)$ & $36.4(-7)$ & $2,294(-25)$ & 6 & $60(-6)$ & $49(-9)$ & $2(-2)$ & $36(-20)$ \\
\hline \multicolumn{10}{|c|}{ Farm labor con- } \\
\hline \multirow{4}{*}{$\begin{array}{l}\text { tractors } \\
\text { Seasonal } \\
\text { agricultural } \\
\text { servicesł } \\
\text { County } \\
\text { agriculture }\end{array}$} & 0761 & $171(-8)$ & $73.3(17)$ & $13,852(7)$ & $27(9)$ & $77(13)$ & $65(10)$ & $44(4)$ & $89(4)$ \\
\hline & 01, & & & & & & & & \\
\hline & 07 & $3,860(-11)$ & $452.8(16)$ & 51,105 & $5(2)$ & $59(7)$ & $48(7)$ & $5(1)$ & $56(6)$ \\
\hline & $\begin{array}{r}01,02 \\
07\end{array}$ & $4,301(-11)$ & $503.2(15)$ & $54,452(-1)$ & $6(2)$ & $58(5)$ & $47(6)$ & $5(1)$ & $54(5)$ \\
\hline \multicolumn{10}{|c|}{$\begin{array}{l}\text { SOURCE: Unemployment Insurance data, California Employment Development Department, } 1989 \\
\text { "A single farm may appear as two reporting units (e.g., if it maintains separate payrolls for grape and dairy op- } \\
\text { erations that each include } \geq 50 \text { employees). } \\
\text { † Average of the } 12 \text { monthly employment totals. } \\
\ddagger \text { Seasonal agricultural services include SIC } 01,071,072 \text {, and } 076 \text {. }\end{array}$} \\
\hline
\end{tabular}

There was little change in the concentration of livestock employment, but the trend was toward less concentration in custom harvesting and labor contractor employment. For example, the number of large labor contractors and their wages paid fell $14 \%$; but since FLC wages rose sharply, the declining importance of large contractors indicated that there were more small and medium-sized FLCs in 1988 than in 1984. Custom harvesters exhibit a similar fragmentation - their number increased, but there were fewer large employers.

The increased concentration of employment on crop farms and the fragmentation of employment in agricultural services did not occur in all major agricultural counties. In Monterey County, the number of large vegetable employers rose from 54 to 57 , but thetotal wages paid by theselargeemployers fell slightly. An explanation for this shift from hiring workers directly to hiring workers through smaller labor contractors is that the smaller FLCs offer to do work more cheaply than large FLCs or workers hired directly.

In Imperial County, a similar decrease in the number of farm employers accompanied a sharp increase in the number of FLCs. The number of general crop farm employers fell from 165 to 139 , but the wages paid by these farms rose $33 \%$. The number of farm labor contractors and the wages paid by FLCs each climbed more than $45 \%$.

The number of grape producers in Fresno County fell by more than 250 , but the wages paid by the remaining producers increased 9\%. Similarly, the number of farm labor contractors fell slightly, while FLC wages rose $17 \%$. In Fresno County, large FLCs increased their share of total FLC wages.

\section{Conclusions}

Unemployment insurance data indicate that a two-tiered farm labor market is emerging. The workers hired directly by crop and livestock farmers are being concentrated on fewer and larger farms, while employment in the expanding labor contractor sector is being fragmented among an increased number of small and medium-sized contractors. These concentration and fragmentation patterns have important implications for the evolution of the farm labor market. For example, if smaller contractors are more likely to hire recently arrived undocumented workers, as has been reported, then their increased importance may make it harder to enforce recently enacted immigration reform legislation.

Philip L. Martin is Professor and Greg Miller is an undergraduate student in the Department of Agricultural Economics, University of California, Davis. The authors are indebted to the California Employment Development Office for the data used in this study and to Regina Benzonelli for computer assistance. 